\title{
Comparison of the protocols for obtaining platelet-rich plasma in dogs: a cellular study
}

\section{André William Masseaux Vidal Júnior ${ }^{1 *}$ (D) Ricardo Siqueira da Silva ${ }^{2}$ Ana Paula Lopes Marques ${ }^{2}$ Heloísa Justen Moreira de Souza ${ }^{2}$}

${ }^{1}$ Programa de Pós-graduação em Medicina Veterinária, Universidade Federal Rural do Rio de Janeiro (UFRRJ), 23890-000, Seropédica, RJ, Brasil. E-mail: andremasseaux@gmail.com. "Corresponding author.

${ }^{2}$ Departamento de Medicina e Cirurgia Veterinária, Universidade Federal Rural do Rio de Janeiro (UFRRJ), Seropédica, RJ, Brasil.

ABSTRACT: This study aimed to evaluate two protocols (PA and PB) that are used to obtain canine platelet-rich plasma (PRP) for cellularity. Twenty healthy dogs were used. Blood samples were collected and placed in two tubes of $3.2 \%$ sodium citrate. PA used double centrifugation at $210 x \mathrm{~g}$, and $370 \times \mathrm{g}$ and $P B$ used double centrifugation with $140 x \mathrm{~g}$ and $330 \mathrm{xg}$. The PRP samples from the protocols were examined in terms of their platelet, erythrocyte, and leukocyte count in the Neubauer chamber, differential leukocyte count and platelet morphological observation in blood smears. Data (mean and standard deviation) were analyzed with the $95 \%$ probability t-test $(P<0.05)$ using Pearson's correlation to test the relationship between platelets and erythrocytes, platelets, and leukocytes, and the leukocyte count versus the erythrocytes. Very weak negative correlation between platelets and leukocytes $(p=-0.03)$, weak negative correlation between platelets and erythrocytes $(p=-0.3)$ and a strong positive correlation between leukocytes and erythrocytes $(\rho=0.75)$ were noted. Although, BP did not reach the desired mean of one million platelets $(979300 \pm 79631$ cells / $\mu L)$, both protocols, A and B (4.42 \pm 1.61 and $3.85 \pm 1.55$ times more platelets than total blood, respectively) $(p<0.05)$ were efficient in concentrating platelets. Platelet activation was present in $26.55 \pm 6.72 \%$ of the PA platelets and 26.25 $\pm 7.03 \%$ in $P B(p>0.05)$. PA and PB presented low erythrocyte concentration ( $p>0.05)$, and PA had more leukocytes $(p<0.05)$ than $P B$, with higher concentrations of basophils that were segmented, and lymphocytes.

Key words: growth factors, platelet-rich plasma, cell therapy, canines.

Comparação entre protocolos para obtenção de plasma rico em plaquetas em cães: estudo celular

RESUMO: Foi proposto avaliar dois protocolos (PA e PB) para obtenção de plasma rico em plaquetas (PRP) canino quanto a celularidade. Foram utilizados 20 cães sadios e coletadas amostras sanguíneas, sendo acondicionados em dois tubos de citrato de sódio a 3,2\%. O PA utilizando centrifugação dupla com $210 x G$ e $370 x G$ e PB utilizando centrifugação dupla com $140 x G$ e $330 x G$. Amostras de PRP dos protocolos foram destinadas a contagem plaquetária, eritrocitária e leucocitária em câmara de Neubauer, contagem diferencial leucocitária e observação morfológica plaquetária em esfregaços sanguíneos. Analisou-se os dados (médias e desvios padrão) pelo Teste t com 95\% de probabilidade $(p<0,05)$ utilizando-se correlação de Pearson para testar a relação entre a contagem de plaquetas e eritrócitos, plaquetas e leucócitos e leucócitos em relação aos eritrócitos. Houve correlação negativa muito fraca entre plaquetas e leucócitos $(\rho=-0,03)$, negativa fraca entre plaquetas e eritrócitos $(\rho=-0,3)$ e correlação positiva forte entre leucócitos e eritrócitos $(\rho=0,75)$. Embora o PB não tenha alcançando a média de um milhão de plaquetas desejado (979300 \pm 79631 células/ $\mu$ L), ambos os protocolos, A e B (4,42 $\pm 1,61$ e 3,85 $\pm 1,55$ vezes mais plaquetas que o sangue total, respectivamente) $(p<0,05)$, foram eficientes em concentrar plaquetas. A ativação plaquetária esteve presente em 26,55 $\pm 6,72 \%$ das plaquetas do PA e 26,25 \pm 7,03\% nas do PB ( $p>0,05)$. PA e PB apresentaram baixa concentração eritrocitária $(p>0,05)$ e PA apresentou mais leucócitos $(p<0,05)$ que $P B$, com maiores concentrações de basófilos, segmentados e linfócitos. Palavras-chave: fatores de crescimento, plasma rico em plaquetas, terapia celular, caninos.

\section{INTRODUCTION}

Platelet-rich plasma (PRP) is generally autologous and consists of a small volume of plasma with a high concentration of platelets, growth factors (GF), and cytokines for epithelial migration, bone and connective tissue formation (MARX, 2004;
CROVETTI et al., 2004; HENDERSON et al., 2003). The PRP quality is mainly measured by the ability to concentrate platelets. The PRP should have three to five times more platelets than whole blood (WHITLOW et al., 2008). However, other studies have indicated that a concentration $>1$ million platelets/ $\mu \mathrm{L}$ is necessary (MARX et al., 1998; LEMOS, 2002). 
Dogs can benefit from PRP, associated or not with other biomaterials, in bone grafts and bone tissue regeneration, and integration in cases of experimental fractures (YOU et al., 2007; CASATI et al., 2007). The semi-automatic PRP processing method using a conventional centrifuge in a laboratory or outpatient environment provides low-cost PRP and greater applicability in veterinary medicine (VENDRAMIN et al., 2006).

All protocols should increase the platelet count to a concentration well above that reported in whole blood, preserving the platelet structure and function. If platelets are activated by releasing the GF earlier, the therapeutic action of PRP will be impaired (LÓPEZ et al., 2012).

High leukocyte concentrations in PRP may delay tendon and joint healing processes due to an increased expression of inflammatory cytokines (McCARREL et al., 2012; SCHNABEL et al., 2007; CARMONA et al., 2007). However, in contaminated skin or bone lesions, the use of PRP with higher leukocyte concentration is beneficial (MARX \& GARG, 1999; BIELECKI et al., 2007; BARBOSA et al., 2008). Red blood cells in PRP may increase gel viscosity after platelet activation (ROSSI, 2001), but pain perception may increase after use due to local irritation (HALPERN et al. 2012).

In this context, the evaluation of two protocols was proposed to obtain autologous canine PRP. These semi-automatic protocols are easy to perform in an outpatient clinic and have good quality levels (platelet concentration capacity, qualitative evaluation of platelet morphology, qualitative and quantitative leukocyte classification, and reduced contamination with red blood cells).

\section{MATERIALS AND METHODS}

The study was approved by the committee on animal research and ethics of the Federal Rural University of Rio de Janeiro (CEUA- UFRRJ) under protocol no. 1827171016. All animal owners signed an informed consent form.

This study included twenty dogs (Canis lupus familiaris) of both sexes treated at the Veterinary Hospital of the Federal Rural University of Rio de Janeiro (UFRRJ), Brazil. All dogs were aged between 1 and 7 years, with a mean age of 4 years. All presented with no clinical changes (routine consultations or elective castration procedures) and underwent blood collection. After shaving and disinfecting the cervical region with $70 \%$ alcohol, the external jugular vein was punctured using a $22 \mathrm{G}$ needle and $10 \mathrm{~mL}$ syringe to collect $10 \mathrm{ml}$ of blood. Of this, $2 \mathrm{ml}$ of blood was transferred to a tube containing ethylenediamine tetraacetic acid (EDTA) anticoagulant for a complete blood count (CBC) and the remaining $8 \mathrm{ml}$ was divided into two $4 \mathrm{ml}$ tubes containing $3.2 \%$ sodium citrate for two PRP protocols.

An impedance hematological analyzer was used for the CBC. An immersion optical microscope with a 100x objective was used for differential leukocyte count using whole blood smear slides that were instantaneously stained (Panótico Rápido ${ }^{\circledR}$ ) (JAIN, 1993). Plasma concentrations of total proteins were measured using refractometry (COLES, 1987).

The blood was centrifuged (Daiki Centrifuge $80-2 \mathrm{~B}$, Centribio $\left.^{\circledR}\right)$ at $210 \mathrm{x}$ for $10 \mathrm{~min}$ for protocol A (PA) (ALEIXO et al., 2011, modified). After separation of the supernatant plasma, leukocyte layer, and red blood cell fraction, the supernatant plasma was divided into two fractions using an automatic micropipette. Subsequently, $50 \%$ (the upper half) of the supernatant plasma was discarded, and the lower half and the leukocyte layer were stored in a Vacutainer tube without additives for the second centrifugation at $370 \mathrm{x} g$ for 10 min. Thereafter, the supernatant plasma and a red blood cell button were visualized. The automatic micropipette was sued to discard $2 / 3$ of the supernatant plasma, and the rest was considered PRP obtained with protocol A (Figure 1). The same procedures were repeated for protocol B (PB) (KIM et al., 2002, adapted) with different centrifugation speeds and plasma fractions. The first centrifugation was at $140 \mathrm{xg}$ for $10 \mathrm{~min}$, and all supernatant plasma was centrifuged a second time at 330 $\mathrm{x} g$ for $10 \mathrm{~min}$. The automatic micropipette was used to discard $2 / 3$ of the supernatant plasma, and the rest was considered PRP obtained with protocol B. The centrifugation strength and time of each protocol was based on protocols described by ALEIXO et al. (2011) and KIM et al. (2002) that are considered efficient in concentrating platelets.

PRP samples obtained from each protocol were diluted and homogenized to count platelets, red blood cells, and leukocytes in a Neubauer chamber after resting in a humidified chamber for $5 \mathrm{~min}$. Counts were duplicated, using the mean values obtained for each sample. PRP was diluted at 1/200 (10 $\mu$ l PRP in $1990 \mu \mathrm{l}$ Brecher liquid with $1 \%$ ammonium oxalate) to determine the number of platelets. The Neubauer chamber was filled with a capillary tube, and after 20 min, an optical microscope with a 40x objective was used for counting the central reticulum (25 central medium squares $=1 \mathrm{~mm}^{2}$ area). To determine the number of red blood cells, the PRP was diluted at $1 / 200$ (10 $\mu \mathrm{l}$ PRP in $1990 \mu \mathrm{l} 0.9 \%$ saline solution), the 


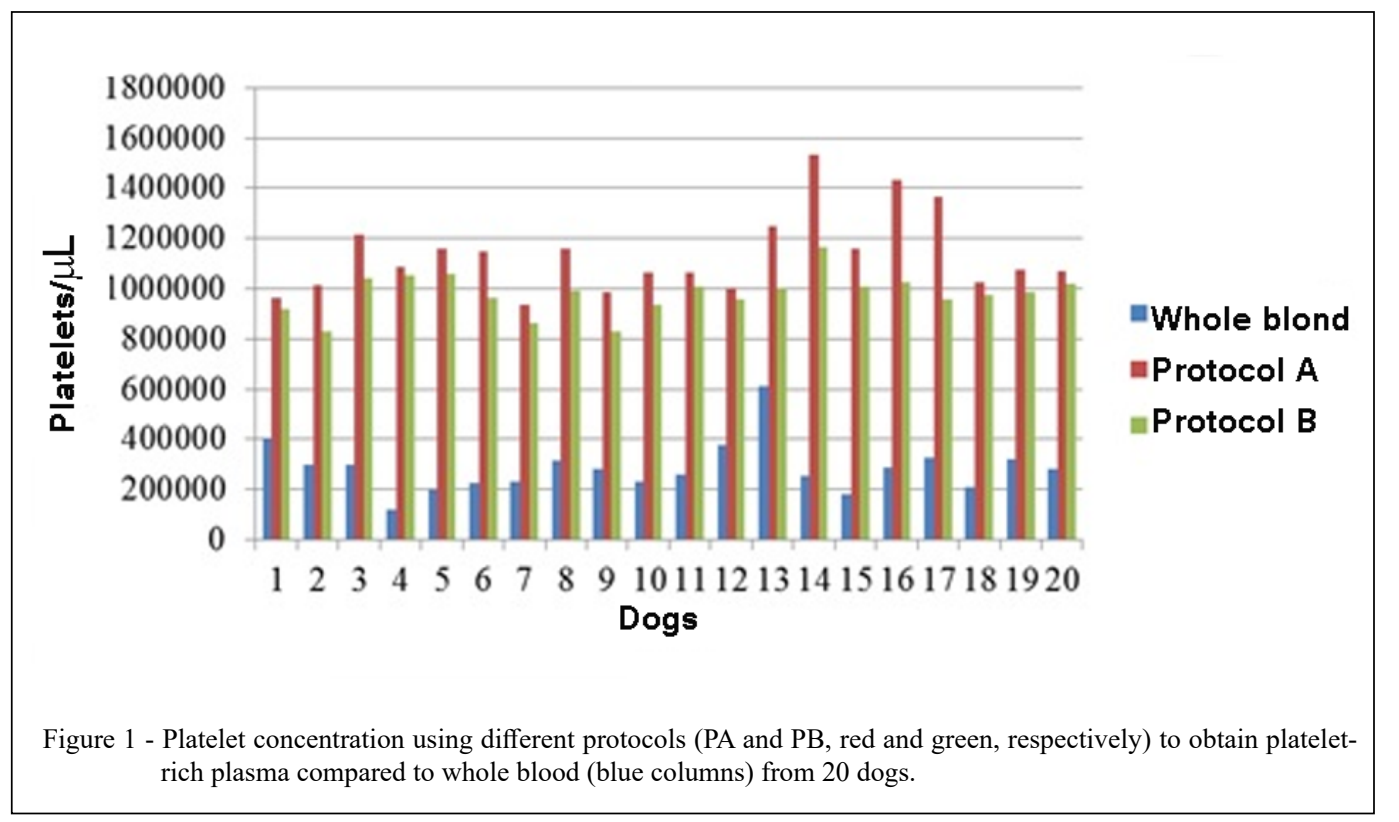

Neubauer chamber was filled with a capillary tube, and after $5 \mathrm{~min}$ an optical microscope with a 40x objective was used for counting the central reticulum (25 central medium squares). For leukocytes, the PRP was diluted at 1/20 (20 $\mu$ PRP in $380 \mu$ Thoma Liquid), the Neubauer chamber was filled with a capillary tube, and after $5 \mathrm{~min}$ an optical microscope with a 40x objective was used for counting the four largest lateral squares $\left(4 \mathrm{~mm}^{2}\right.$ area).

The formula used to obtain the total number of cells, platelets, red blood cells, and leukocytes per $\mu \mathrm{l}$ of PRP was the number of cells counted $\mathrm{x}$ dilution $\mathrm{x} 10(0.1 \mathrm{~mm}$ height $) \mathrm{x}$ area, as described by COLES (1984).

Differential leukocyte counts were performed using thin, uniform PRP smear slides that were instantaneously stained (Panótico Rápido ${ }^{\circledR}$ ) and visualized under an optical microscope in immersion with a 100x objective. The count started from the middle region of the smear and extended towards the tail, zigzagging through the slide. In total, 100 leukocytes were counted, and the result was presented as a percentage (relative leukocyte count). The absolute specific leukocyte count of each PRP was determined by the relationship between the global and relative specific leukocyte counts. The smear slides were used to visualize platelet morphology, with 100 platelets being counted. Their conformation was observed through pseudopod formation when activated, with the result presented as a percentage.
The confidence level was $95 \%$, with a maximum error of $5 \%$, and the standard deviation of the population in the pilot test did not exceed 10 points. Results are presented as a mean, standard deviation, and minimum and maximum values. The data were analyzed using the t-test with a $95 \%$ probability $(p<0.05)$. Pearson's correlation was used to test the relationship between platelet and red blood cell counts, platelets and leukocytes, and leukocytes and red blood cells. Prism version 6.0 software for Windows (GraphPad Software, California, USA) and Microsoft Excel 2010 software were used for the analyses.

\section{RESULTS AND DISCUSSION}

Table 1 presents a summary of the data of the variables (platelets, red blood cells, and leukocytes) in whole blood and in each protocol evaluated. Figure 1 shows that in both the PRP protocols the number of platelets differed $(p<0.05)$ in relation to whole blood using a manual method for platelet concentration counting in PRP for its concomitant morphological evaluation and activation analysis.

The protocols were selected for being simple, low-cost, and efficient at concentrating platelets (ALEIXO et al., 2011; KIM et al., 2002). However, leukocytes and red blood cells were not evaluated in previous studies.

Platelet concentration in PRP should be three to five times higher than in whole blood 
Table 1 - Mean values of the platelets, red blood cells, and leukocytes obtained by the two protocols using whole blood and plasma rich in platelets from 20 dogs.

\begin{tabular}{|c|c|c|c|}
\hline & WHOLE BLOOD & Protocol A & Protocol B \\
\hline \multicolumn{4}{|c|}{ - } \\
\hline Mean & 285000 & 1135300 & 979300 \\
\hline SD & 101359 & 158779 & 79631 \\
\hline Minimum & 118000 & 934000 & 830000 \\
\hline Maximum & 609000 & 1536000 & 1162000 \\
\hline \multicolumn{4}{|c|}{ 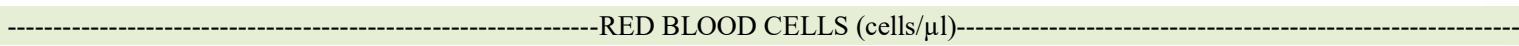 } \\
\hline Mean & 6577000 & 67800 & 59600 \\
\hline SD & 906480 & 38437 & 48300 \\
\hline Minimum & 5040000 & 20000 & 10000 \\
\hline Maximum & 8970000 & 148000 & 188000 \\
\hline \multicolumn{4}{|c|}{ 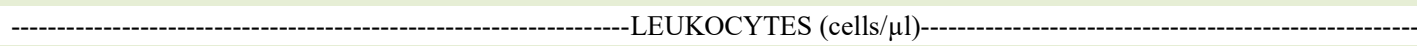 } \\
\hline Mean & 12360 & 2740 & 1665 \\
\hline $\mathrm{SD}$ & 6080 & 1056 & 1154 \\
\hline Minimum & 6100 & 1250 & 550 \\
\hline Maximum & 33100 & 4850 & 4350 \\
\hline
\end{tabular}

(WHITLOW et al., 2008). Therefore, both protocols, $\mathrm{PA}$ and PB $(4.42 \pm 1.61$ and $3.85 \pm 1.55$ times more platelets than whole blood, respectively) were efficient in concentrating platelets but differed $(\mathrm{P}<0.05)$ from one another (Table 2). However, other studies considered a concentration higher than 1 million platelets/ $\mu \mathrm{L}$ (MARX et al., 1998; LEMOS, 2002). According to these authors, PB would not be considered a quality test for presenting a mean platelet concentration of $979,300 \pm 79,631$ cells $/ \mu \mathrm{L}$ (Table 1). Platelet activation did not differ $(p>0.05)$ between protocols and was relatively low (Table 2 ).

The microscopic morphological visualization of platelets using a PRP smear is recommended to evaluate the quality of the blood component, since pseudopods are formed after activation (WEISS; WARDROP, 2010), releasing growth factors in advance (EPPLEY et al., 2004). A previous study showed no morphological changes in PRP platelets obtained by direct microscopy (ALEIXO et al., 2011). However, a study using electronic microscopy to visualize platelet morphology in PRP detected $49 \%$ of platelets with uncertain activation, $41 \%$ at rest, $9 \%$ activated, and $1 \%$ damaged (ZANDIN et al., 2012). The present study detected small cytoplasmic prolongations evidencing platelet activation in $26.55 \pm 6.72 \%$ of the PA platelets, and $26.25 \pm 7.03 \%$ of PB platelets, with no statistical difference between them. However, the optimal amount of inactive platelets has not been established.
Red blood cells are considered PRP sample contaminants (MARX, 2004). Both protocols were considered of good quality, as demonstrated by reduced red blood cell concentration with no difference ( $p>0.050)$ among the evaluated PRPs (Table 2).

A lower number of red blood cells was previously correlated with lower gravitational force (PEREIRA, 2012), which corroborates our data since $P B$ showed lower gravitational force $(140 \mathrm{x} g$ and 330 $\mathrm{x} g)$ than PA $(210 \mathrm{xg}$ and $370 \mathrm{xg})$ and concentrated less red blood cells. According to PEREIRA (2012), lower gravitational force protocols concentrate fewer platelets, which would reduce the quality of the final product. This differs from studies with equine blood, in which higher platelet counts were associated with lower centrifugal forces (VENDRUSCOLO et al., 2012). When evaluating the number of leukocytes in the PRPs, PA showed more white blood cells, significantly differing $(p<0.05)$ from PB (Table 2$)$.

A study on cell proliferation in tendinous lesions using plasma rich in leukocyte platelets (L-PRP) and plasma rich in pure platelets (P-PRP) showed that both treatments induced the differentiation of progenitor tendon cells into active tenocytes. However, L-PRP induced predominantly catabolic and inflammatory changes in differentiated tenocytes, increased the expression of catabolic marker genes, matrix metalloproteinases (MMP), interleukin-1beta (IL-1 $\beta$ ), IL-6, tumor necrosis factor-alpha (TNF- $\alpha$ ), and prostaglandin E2 (PGE 2) production. Contrastingly, P-PRP mainly induced

Ciência Rural, v.50, n.3, 2020. 
Table 2 - Statistical summary of the percentage of platelets, mean percentage of activated platelets, percentage of red blood cells, and percentage of leukocytes in both protocols (PA and PB) to obtain platelet-rich plasma from 20 dogs.

\begin{tabular}{|c|c|c|c|c|c|c|c|c|}
\hline \multicolumn{3}{|c|}{----Platelets $\left(\%\right.$ mean over whole blood $\left.{ }^{*}\right)$---- } & \multicolumn{2}{|c|}{----Activated platelets $(\%)---$} & \multicolumn{2}{|c|}{$\begin{array}{l}\text { Red blood cells ( } \% \text { of } \\
\text { whole blood) }\end{array}$} & \multicolumn{2}{|c|}{$\begin{array}{c}\text { Leukocytes }(\% \text { of whole } \\
\text { blood) }\end{array}$} \\
\hline & Protocol A & Protocol B & Protocol A & Protocol B & Protocol A & Protocol B & Protocol A & Protocol B \\
\hline Mean \pm SD & $\begin{array}{c}442.13 \pm \\
161.93 \mathrm{a}\end{array}$ & $\begin{array}{l}385.70 \pm \\
155.05 \mathrm{~b}\end{array}$ & $\begin{array}{c}26.55 \pm \\
6.72 \mathrm{c}\end{array}$ & $26.25 \pm 7.03 \mathrm{c}$ & $\begin{array}{l}1.04 \pm \\
0.60 \mathrm{~d}\end{array}$ & $\begin{array}{r}0.90 \pm \\
0.72 \mathrm{~d}\end{array}$ & $\begin{array}{c}26.41 \pm \\
16.10 \mathrm{e}\end{array}$ & $\begin{array}{c}15,25 \pm \\
11,84 \mathrm{f}\end{array}$ \\
\hline Minimum & 205.25 & 164.53 & 11 & 13 & 0.30 & 0.15 & 10.27 & 5,13 \\
\hline Maximum & 918.64 & 893.22 & 39 & 57 & 2.42 & 3.07 & 72.13 & 45,90 \\
\hline p-value & \multicolumn{2}{|c|}{-------------0.0003----------- } & & 0.89 & \multicolumn{2}{|c|}{--------------0.48------------- } & \multicolumn{2}{|c|}{-------------0.01-------------' } \\
\hline
\end{tabular}

Data on the same line, followed by different letters indicate a statistical difference with $95 \%$ confidence.

"Mean values found after individually correlating the value in whole blood in relation to protocols A and B for each animal.

anabolic changes, increased the genetic expression of anabolic genes, smooth muscle actin, and type I and III collagen (ZHOU et al., 2015). Only the use of P-PRP in intra-articular injections was indicated as safe to avoid catabolism and failure in tissue recovery (MATTEO et al., 2016).

There were improvements in bone and soft tissue healing processes with the use of L-PRP (YUAN et al., 2012). The PRP with a high leukocyte concentration associated with experimental fracture of the tibia in dogs resulted in a faster and more efficient repair when compared to the control group without PRP (BARBOSA et al., 2008). Therefore, PRP obtained by protocol A would be the most appropriate in fracture cases. Some studies cite the protective effect PRP against infections due to leukocytes (MARX \& GARG, 1999; BIELECKI et al., 2007). In the present study, both protocols obtained lower leukocyte concentrations than whole blood, reducing possible harmful effects of such cell types on tissue repair. Values related to specific leukocyte counts are presented in table 3.

Basophils have a primary function of releasing histamine in response to allergens. Histamine increases blood flow, resulting in increased inflammation, and also stimulates neutrophils and eosinophils to leave the bloodstream to destroy antigens, with neutrophils being the first to activate cellular defense. Under basophilic signaling, neutrophils respond immediately by releasing enzymes that act by suppressing various bacteria and antigens as well as cytokines and GFs that help regeneration. Without basophils, neutrophils respond to damaged tissue or invasive bacterial protein signs (WEISS \& WARDROP, 2010). PRP with a high concentration of basophils, such as that from PA, should be avoided in a tissue in which a reduced inflammatory response is desired.

A large number of neutrophils in PRP release MMPs that can lead to increased muscle damage after injury. The concentration of neutrophils in PRP has been shown to correlate positively with the expression of catabolic MMP-3 and MMP-13 in equine tendon explants, supporting the correlation between increased concentration not only of platelets, but also of leukocytes, and elevated levels of some inflammatory cytokines. This suggested a loss and possible adverse effect of white blood cells on the healing of particular tissues (SCHNABEL et al., 2007). Considering the catabolic effect of MMP, PRPs rich in neutrophils should be avoided in tendinous lesions and osteoarticular infiltrations. However, they are highly functional in bone lesions due to their antimicrobial and bone regeneration properties (BARBOSA et al., 2008).

A previous study showed the presence of white blood cells, particularly concentrated in PRP, predominantly lymphocytes (UBEZIO et al., 2014). They showed that the total biomodulator content, such as GF, in autologous plasma rich in platelets is not influenced by the lymphocyte status (UBEZIO et al., 2014). A longer time in centrifugation slightly increased platelet recovery and decreased leukocyte concentrations in the upper layer. Therefore, time can be a control parameter when low levels of white blood cells, such as lymphocytes, are required in the PRP sample (PEREZ et al., 2014).

\section{CONCLUSION}

Both protocols concentrated platelets efficiently, with no difference between platelet 
Table 3 - Mean values of the absolute specific leukocyte count using the two protocols to obtain platelet-rich plasma from 20 dogs.

\begin{tabular}{|c|c|c|}
\hline & Protocol A & Protocol B \\
\hline & \multicolumn{2}{|c|}{--------------------------------------------------------Basophil------------------------------------------------------- } \\
\hline Mean \pm SD & $8.15 \pm 15.04 \mathrm{a}$ & $0 \pm 0 \mathrm{~b}$ \\
\hline Minimum & 0 & 0 \\
\hline Maximum & 45 & 0 \\
\hline p-value & \multicolumn{2}{|c|}{ 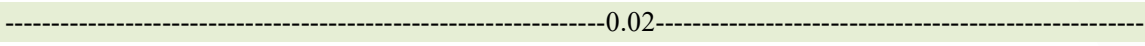 } \\
\hline \multicolumn{3}{|c|}{ 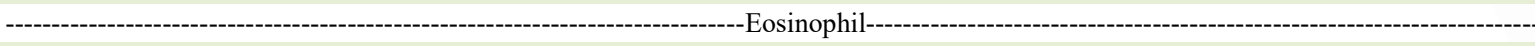 } \\
\hline Mean \pm SD & $19.12 \pm 42.74 \mathrm{a}$ & $18,65 \pm 42,66 a$ \\
\hline Minimum & 0 & 0 \\
\hline Maximum & 176 & 168 \\
\hline p-value & \multicolumn{2}{|c|}{ 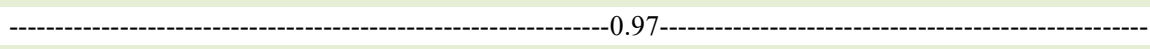 } \\
\hline -------- & 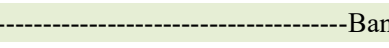 & - \\
\hline Mean \pm SD & $79.45 \pm 38.79 a$ & $64,15 \pm 69,15 \mathrm{a}$ \\
\hline Minimum & 42 & 5,5 \\
\hline Maximum & 178 & 300 \\
\hline p-value & \multicolumn{2}{|c|}{ 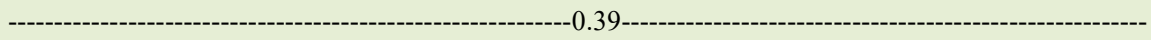 } \\
\hline \multicolumn{3}{|c|}{ 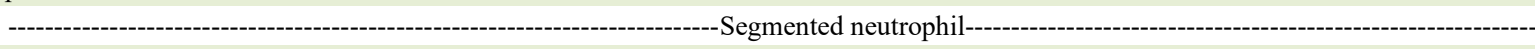 } \\
\hline Mean \pm SD & $410.25 \pm 143.44 a$ & $244,25 \pm 162,83 b$ \\
\hline Minimum & 196 & 83 \\
\hline Maximum & 780 & 713 \\
\hline p-value & \multicolumn{2}{|c|}{ 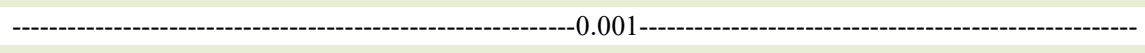 } \\
\hline \multicolumn{3}{|c|}{ 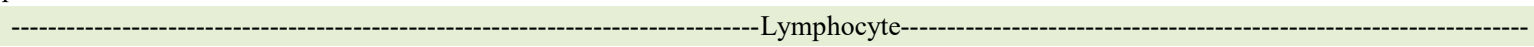 } \\
\hline Mean \pm SD & $2214.72 \pm 922.92 \mathrm{a}$ & $1340,2 \pm 949,58 b$ \\
\hline Minimum & 988 & 451 \\
\hline Maximum & 4074 & 3785 \\
\hline p-value & - & - \\
\hline \multicolumn{3}{|c|}{ } \\
\hline Mean \pm SD & $2.22 \pm 9.95 \mathrm{a}$ & $0 \pm 0 \mathrm{a}$ \\
\hline Minimum & 0 & 0 \\
\hline Maximum & 45 & 0 \\
\hline p-value & ------------------------------------------- & ------------------------------------------- \\
\hline
\end{tabular}

Data on the same line, followed by different letters indicate a statistical difference with $95 \%$ confidence.

activations. However, only PA reached a mean concentration higher than 1 million platelets $/ \mu \mathrm{L}$.

PA resulted in PRP with a higher leukocyte concentration than PB. Both protocols concentrated more lymphocytes in relation to other leukocyte types. PA yielded PRP with higher concentrations of basophils, neutrophils, and lymphocytes than PB.

There was no difference in the red blood cell concentration obtained between the two protocols.

\section{ACKNOWLEDGEMENTS}

This study was financed in part by Coordenação de Aperfeiçoamento de Pessoal de Nível Superior-Brasil (CAPES) Finance code 001 .

\section{BIOETHICS AND COMMITTEE APPROVAL}

This study was approved by the Committee on Animal Research and Ethics of the Federal Rural University of Rio de Janeiro (CEUA-IV, UFRRJ), under protocol no. 1827171016. All animal owners signed a free and informed consent form.

\section{DECLARATION OF CONFLICT OF INTERESTS}

The authors declare no conflict of interest. The founding sponsors had no role in the design of the study; in the collection, analyses, or interpretation of data; in the writing of the manuscript; and in the decision to publish the results. 


\section{AUTHORS' CONTRIBUTIONS}

The authors contributed equally to the manuscript.

\section{REFERENCES}

ALEIXO, G. A. S. et al. Comparação entre dois protocolos para obtenção de plasma rico em plaquetas, em cães. Arquivo Brasileiro de Medicina Veterinaria e Zootecnia, v.63, n.3, p.567-573, 2011 Available from: $<$ http://www.scielo.br/scielo.php?pid=S0102$09352011000300005 \&$ script $=$ sci_abstract\&tlng=pt $>$. Accessed: Apr. 16, 2017.

BARBOSA, A. L. T. et al. Plasma rico em plaquetas para reparação de falhas ósseas em cães. Ciência Rural, v.38, n.5, p.1335-1340, 2008. Available from: <http://www.scielo. $\mathrm{br} / \mathrm{scielo} . \mathrm{php}$ ?pid $=\mathrm{S} 0103-84782008000500021 \& \mathrm{script}=\mathrm{sci}$ abstract\&tlng=pt $>$. Accessed: Mar. 16, 2017.

BIELECKI, T. M. et al. Antibacterial effect of autologous platelet gel enriched with growth factors and other active substances: an in vitro study. Journal of Bone and Joint Surgery, v.89, p.417-420, 2007. Available from: <https://www.ncbi.nlm.nih.gov/ pubmed/17356164>. Accessed: Apr. 24, 2017.

CARMONA, J. U. et al. Autologous platelet concentrates as a treatment of horses with osteoarthritis: a preliminary pilot clinical study. Journal of Equine Veterinary Science, v.27, n.4, p.167-170, 2007. Available from: <https://www.sciencedirect. com/science/article/abs/pii/S0737080607000846>. Accessed: Feb. 19, 2017.

CASATI, M. Z. et al. Platelet-rich plasma does not improve bone regeneration around peri-implant bone defects--a pilot study in dogs. International Journal of Oral and Maxillofacial Surgery, v.36, n.2, p.132-136, 2007. Available from: <https://www.ncbi. nlm.nih.gov/pubmed/16890407>. Accessed: Mar. 26, 2017.

COLES, E. H. Veterinary Clinical Pathology, 4 ed. Philadelphia: Lea \& Febiger, 1987, 421p.

CROVETTI, G. et al. Platelet gel for healing cutaneous chronic wounds. Transfusion and Apheresis Science, v.30, n.2, p.145151, 2004. Available from: $<$ http://prp.net.br/adm/pdf/Crovetti\%20 2004\%20Platelet $\% 20 \mathrm{Gel} \% 20$ for $\% 20$ chronic $\% 20$ wounds.pdf>. Accessed: Apr. 14, 2017.

EPPLEY, B.L. et al. Platelet quantification and growth factor analysis from platelet-rich plasma: implications for wound healing. Plastic Reconstructive Surgery, v.114, p.15021508, 2004. Available from: <https://www.ncbi.nlm.nih.gov/ pubmed/15509939>. Accessed: Apr. 14, 2017

HALPERN, B. C. et al. The role of platelet-rich plasma in inducing musculoskeletal tissue healing. HSS Journal, v.8, n.2, p.137-145, 2012. Available from: <https://www.ncbi.nlm.nih.gov/pmc/ articles/PMC3715623/>. Accessed: Apr. 14, 2017.

HENDERSON, J. L. et al. The effects of autologous platelet gel on wound healing. Ear Nose Throat Journal, v.82, n.8, p.598602, 2003. Available from: <https://www.ncbi.nlm.nih.gov/ pubmed/14503096>. Accessed: Apr. 14, 2017

JAIN, N. C. Veterinary Hematology. Philadelphia: Lea \& Febger, $1993.417 \mathrm{p}$.
KIM, S. G. et al. A comparative study of osseointegration of avana implants in a demineralized freeze-dried boné alone or with platelet-rich plasma. Journal of Oral and Maxillofacial Surgery, v.60, p.1018-1025, 2002. Available from: <https://www.ncbi.nlm. nih.gov/pubmed/12215987>. Accessed: Apr. 14, 2017.

LEMOS, J. J. Utilização de PRP em enxertos ósseos - Proposta de um protocolo de obtenção simplificado. 2002. Online. Disponível em: <http://www.dentaria.com/artigos/ver/?art=58> Accessed: Dec. 08, 2016. Available from: $<$ http://www.dentaria. com/artigos/ver/?art=58>. Accessed: Dec. 08, 2016.

LÓPEZ, C. et al. Evaluación de un método de doble centrifugación en tubo para concentrar plaquetas bovinas: estudio celular. Archivos de medicina veterinaria, v.44, p.109115, 2012. Available from: <https://scielo.conicyt.cl/scielo. php? script $=$ sci_arttext\&pid $=$ S0301-732X2012000200003 $>$. Accessed: Dec. 08, 2016.

MARX, R. E. et al. Platelet-rich plasma: growth factor enhancement for bone grafts. Oral Surgery Oral Medicine Oral Pathology Oral Radiology and Endodontics, v.85, n.6, p.638646, 1998. Available from: <https://www.ncbi.nlm.nih.gov/ pubmed/9638695>. Accessed: Jan. 19, 2017.

MARX, R. E.; GARG, A. K. Bone graft physiology with use of platelet-rich plasma and hiperbaric oxygen. In.: The sinus bone graft. Colorado: Quintessense, p.183-189, 1999.

MARX, R. E. Platelet-rich plasm: evidence to support its use. Journal of Oral and Maxillofacial Surgery, v.62, n.4, p.489496, 2004. Available from: <http://www.drkoprp.com/pdfs/prp/ PRPbyDr.Marx.pdf>. Accessed: Apr. 03, 2017.

MCCARREL, T. et al. Optimization of leukocyte concentration in platelet-rich plasma for the treatment of tendinopathy. The Journal of Bone and Joint Surgery, v.94, n.143, p.141148, 2012. Available from: <https://www.ncbi.nlm.nih.gov/ pubmed/23032594>. Accessed: Apr. 14, 2017.

PEREIRA, R. C. F. Avaliação de sete protocolos de obtenção de plasma rico em plaquetas (PRP). 2012. Dissertação de Mestrado em Medicina Veterinária. Santa Maria, RS, Brasil:Universidade Federal de Santa Maria- Centro de Ciências Rurais, 2012. Available from: <http://www.scielo.br/scielo.php?pid=S0103$84782013000600028 \&$ script $=$ sci abstract\&tlng=pt $>$. Accessed: Apr. 14, 2017.

PEREZ, A. G. et al. Relevant aspects of centrifugation step in the preparation of platelet-rich plasma. International Scholarly Research Notices: Hematology, v.2014, p.1-8, 2014. Available from: <https://www.hindawi.com/journals/isrn/2014/176060/>. Accessed: Jan. 10, 2017.

SCHNABEL, L. V. et al. Platelet rich plasma (PRP) enhances anabolic gene expression patterns in flexor digitorum superficialis tendons. Journal of Orthopedic Research, v.25, p.230 240, 2007. Available from: <https://www.ncbi.nlm.nih.gov/ pubmed/17106885>. Accessed: Apr. 14, 2017.

UBEZIO, G. et al. Bio-modulators in platelet-rich plasma: a comparison of the amounts in products from healthy donors and patients produced with three different techniques. Blood Transfusion. v.12, Suppl.1, p.214-220, 2014. Available from: $<$ https://www.ncbi.nlm.nih.gov/pmc/articles/PMC3934217/>. Accessed: Jun. 27, 2016. 
VENDRAMIN, F. S. et al. PRP e FC: técnica de obtenção e utilização em cirurgia plástica. Revista do Colégio Brasileiro de Cirurgiões, v.33, n.1, p.24-28, 2006. Available from: $<$ http://www.scielo.br/scielo.php?script $=$ sci_arttext\&pid $=$ S0100-69912006000100007>. Accessed: Apr. 14, 2017.

VENDRUSCOLO, C. P. et al. Plasma rico em plaquetas: uma nova perspectiva terapêutica para medicina equina. Veterinária e Zootecnia, v.19, n.1, p.33-43, 2012. v.19, n.1,from: <https:// www.researchgate.net/publication/258262654_PLASMA RICO EM PLAQUETAS UMA NOVA PERSPECTIVA TERAPEUTICA_PARA_MEDICINA_EQUIN̄A $>$. Accessed: Apr. 14, 2017.

WEISS, D. J., WARDROP, K. J. Schalm's veterinary hematology. 6 ed. Iowa: Blackwell Publishing. p.1232, 2010.

WHITLOW, J. et al. Barriers to the acceptance and use of autologous platelet gel. Perfusion, v.23, p.283-289, 2008. Available from: $<$ https://www.ncbi.nlm.nih.gov/pubmed/19346267>. Accessed: Apr. 14, 2017.

YOU, T. M. et al. The effect of platelet-rich plasma on bone healing around implants placed in bone defects treated with Bio-Oss: a pilot study in the dog tibia. Oral Surgery, Oral Medicine, Oral Pathology, Oral Radiology, and Endodontics, v.103, n.4, p.8-12, 2004. Available from: <https://www. google.com/search?q=The + effect + of + platelet-rich + plasma + on + bone+healing + around + implants + placed + in + bone + defect $\mathrm{s}+$ treated + with + Bio-Oss $\% 3 \mathrm{~A}+\mathrm{a}+$ pilot + study $+\mathrm{in}+$ the + dog + ti bia\&oq $=$ The + effect + of + platelet-rich + plasma + on + bone + heal ing + around + implants + placed + in + bone + defects + treated + with + Bio-Oss $\% 3 \mathrm{~A}+\mathrm{a}+$ pilot + study + in + the + dog + tibia\&aqs $=$ chrom e..69i57.2573j0j4\&sourceid $=$ chrome $\& \mathrm{ie}=\mathrm{UTF}-8>$. Accessed: May, 12, 2017.

YUAN, T. et al. Applications of leukocyte-and platelet-rich plasma (L-PRP) in trauma surgery. Current Pharmaceutical Biotechnology, v.13, n.7, p.1173-1184, 2012. Available from: <https://www.researchgate.net/publication/51478027 Applications_of_Leukocyte-_and_Platelet-Rich_Plasma_LPRP in Trauma Surgery>. Accessed: Apr. 14, 2017.

ZANDIM, B. M. et al. Platelet activation: Ultrastructure and morphometry in platelet-rich plasma of horses. Pesquisa Veterinária Brasileira, v.32, n.1, p.83-92, 2012. Available from: $<$ http://www.scielo.br/scielo.php?script=sci_arttext\&pid=S0100736X2012000100014>. Accessed: Mar. 07, 2017.

ZHOU, Y. et al. The differential effects of leukocyte-containing and pure platelet-rich plasma (PRP) on tendon stem/progenitor cells - implications of PRP application for the clinical treatment of tendon injuries. Stem Cell Research \& Therapy, v.6, n.1, p.173, 2015. Available from: <https://www.google.com/search?q=The+ differential+effects + of + leukocyte-containing + and + pure + plateletrich + plasma $+($ PRP $)+$ on + tendon + stem $\% 2$ Fprogenitor + cells + + implications + of + PRP + application + for + the + clinical + treatment + of + tendon+injuries.\&oq $=$ The + differential + effects + of + leukocytecontaining + and + pure + platelet-rich + plasma $+(P R P)+$ on + tendon + ste $\mathrm{m} \% 2$ Fprogenitor + cells +-+ implications + of + PRP + application + for + the + clinical + treatment + of + tendon + injuries. \&aqs $=$ chrome..69i57.2 575j0j4\&sourceid=chrome\&ie=UTF-8>. Accessed: Jun. 23, 2016. 